\title{
Interferon Lambda-3
}

National Cancer Institute

\section{Source}

National Cancer Institute. Interferon Lambda-3. NCI Thesaurus. Code C106357.

Interferon lambda-3 (196 aa, $22 \mathrm{kDa}$ ) is encoded by the human IFNL3 gene. This protein plays a role in cytokine signaling. 